\title{
Zagrebačka stanogradnja u prijedlozima planova i generalnim urbanističkim planovima od 1945. do 1990.*
}

\author{
LIDIJA BENCETIĆ \\ Hrvatski institut za povijest \\ Zagreb, Hrvatska \\ lidija.bencetic@gmail.com
}

Rješenje stambenoga pitanja svakoga člana društva, kao i kvaliteta njegove realizacije, jedan je od ključnih izazova svakoga društva kao cjeline, ali i svakoga političkog sustava. U razdoblju socijalizma to je pitanje jedan od glavnih društvenih i političkih problema, koji se na razini gradova nastojalo riješiti kreiranjem sveobuhvatne stambene politike koja se pokušala ostvariti generalnim urbanističkim planovima i urbanističkim programima. U gradu Zagrebu na toj se problematici radilo kontinuirano u Urbanističkom zavodu grada Zagreba i njegovim pravnim prethodnicima, prije svega preko urbanističkih prijedloga i planova objavljenih 1949., 1953., 1965., 1971. i 1986. godine. Istraživanje se temelji na generalnim urbanističkim planovima Zagreba (regulatorne osnove), jednome programu urbanističkoga razvoja i dva prijedloga urbanističkoga razvoja: Vlado Antolić, „Regulacioni plan i direktivna regulaciona osnova Zagreba" (1949.); Zagreb: direktivna regulatorna osnova Zavoda za urbanizam NOGZ 1953. (1953.); Urbanistički program grada Zagreba: smjernice za razvoj (1965.); Generalni urbanistički plan grada Zagreba: elaborat (1970.); Generalni urbanistički plan grada Zagreba: sažetak (1985.). Ovim se radom nastoji ustanoviti koja su sustavna rješenja predviđena, kakve su bile projekcije razvoja grada i kretanje broja stanovništva te kakva je bila realizacija urbanističkih prijedloga i planova.

\footnotetext{
* Ovo je istraživanje financirala Hrvatska zaklada za znanost projektom IP-2016-06-2015 Modernizacija urbanog života u Hrvatskoj kroz prizmu razvoja komunalne infrastrukture u 19. i 20. stoljeću.
} 
Ključne riječi: Zagreb; Hrvatska; Jugoslavija; socijalizam; stambena izgradnja; stambeno pitanje; generalni urbanistički plan; regulatorne osnove; urbanizam

\section{Uvod}

Prvo poslijeratno urbanističko planiranje Zagreba do 1953. oslanjalo se na prijeratni urbanistički plan (Generalni regulacioni plan grada Zagreba) koji je predložen 1936., prihvaćen 1937., a na snagu je stupio 1940. godine. ${ }^{1}$ Pod vodstvom arhitekta i urbanista Vlade Antolića² 1949. predstavljena je prva poslijeratna verzija urbanističkoga plana Zagreba („Regulacioni plan i direktivna regulaciona osnova Zagreba”), a 1953. i dopunjena verzija (Zagreb: direktivna regulatorna osnova Zavoda za urbanizam NOGZ 1953.), kojima je planirana urbanizacija i razvoj Zagreba u idućih trideset godina. Međutim, tijela gradske uprave nisu prihvatila objedinjene planove iz 1949. i 1953. zbog „nedovoljne ambicije u širenju grada i neslaganja oko rješenja problema željezničke pruge", zbog čega Zagreb i dalje službeno ostaje bez generalnoga urbanističkog plana, ali u nedostatku službenoga plana razvoja grada korišteni su spomenuti prijedlozi. ${ }^{3}$ Takvo stanje bilo je veliki problem u upravljanju razvojem grada jer upravo je tada bilo razdoblje najvećega porasta stanovništva i razvoja, ujedno i razdoblje kada je grad Zagreb „prešao” rijeku Savu i kada nastaje potpuno novi dio grada - Južni Zagreb ili Novi Zagreb. Godine 1963. pod vodstvom direktora Urbanističkoga zavoda grada Zagreba (dalje: Urbanistički zavod) Zdenka Kolacija ${ }^{4}$ predstavljen je novi urbanistički program, ujedno prvi urbanistički program razvoja Zagreba nakon Drugoga svjetskog rata koji će 1965. prihvatiti Skupština grada Zagreba - Urbanistički program grada Zagreba: smjernice za razvoj. Međutim, njegova razina niža je od razine generalnoga urbanističkog plana. Prvi generalni urbanistički plan socijalističkoga Zagreba prihvaćen je tek 1971. (Generalni urbanistički plan grada Zagreba: elaborat), a najzaslužniji za njegov nastanak su direktor Urbanističkoga zavoda Zdenko Kolacio i urbanist Josip Uhlik. Zbog nastavka ubrzanoga razvoja grada novi, drugi generalni urbanistički plan Zagreba, ujedno i posljednji u socijalizmu, prihvaćen je 1986. godine (Generalni urbanistički plan grada Zagreba), a potpisuju ga urbanist

DELALLE, 25 godina Urbanističkog zavoda grada Zagreba, 4.

2 Vladimir (Vlado) Antolić, urbanist i arhitekt (Dežanovec, 4. lipnja 1903. - Zagreb, 13. svibnja 1981.), od 1947. do 1951. direktor Urbanističkoga instituta NR Hrvatske, od 1951. do lipnja 1953. direktor Zavoda za urbanizam Narodnoga odbora grada Zagreba (koji poslije mijenja ime u Urbanistički zavod grada Zagreba). Vidi: „Antolić, Vlado”.

3 Urbanistički program grada Zagreba: smjernice za razvoj, 10; DOMLJAN, „Poslijeratna arhitektura u Hrvatskoj", 94.

4 Zdenko Kolacio, urbanist i arhitekt (Sušak, 24. rujna 1912. - Zagreb, 18. svibnja 1987.), od 1956. do 1971. direktor Urbanističkoga zavoda grada Zagreba. Vidi: „Kolacio, Zdenko”. 
i arhitekt Slavko Dakić i direktor Urbanističkog zavoda Aleksandar Bakal. ${ }^{5}$ Koliko su ljudi koji su vodili Zagreb u socijalizmu davali zamaha njegovoj urbanizaciji vidi se već iz same činjenice da su u tom razdoblju donesena dva generalna urbanistička plana, jedan dokument niže razine te dva prijedloga, a u ranijoj povijesti planiranja Zagreba od 1850. postoje samo tri dokumenta razine generalnih planova - Regulatorna osnova iz 1865., Regulatorna osnova iz 1887./1889. i Regulatorni plan iz 1936./1937. godine. ${ }^{6}$

Stambeno planiranje odnosno stambena izgradnja, uz pitanja lociranja industrije, prostora javne namjene, prometa, infrastrukture, zona rekreacije i zelenih zona, najvažniji je segment svakoga prijedloga urbanističkoga programa i generalnoga urbanističkog plana. Stambena je izgradnja, dakako, i važno društveno i političko pitanje kojemu se pridaje veliko značenje u cijelome istraživanom razdoblju. Kroz odnos prema stambenoj problematici mogu se pratiti urbanistički trendovi u Hrvatskoj, a u njoj se svakako ogleda i odnos vlasti i ideologije prema društvu u cjelini ili, kako kazuje Slavko Dakić: „Pitanje grada' - a ne samo 'pitanje stana' - jedno je od sintetskih političkih tema našeg vremena. Ono poput zrcala ocrtava društvene odnose, klasne i interesne sukobe oko prostora i prioriteta, odnos prema prošlosti i budućnosti i shvaćanja prirode jednoga grada."

Stambena je politika u socijalističkome razdoblju imala dvostruki značaj: s jedne strane trebala je udovoljiti ideološkim potrebama vlasti, a s druge strane riješiti realne ekonomske, socijalne, komunalne i ekološke probleme. ${ }^{8}$ Ideološki gledano, socijalistički su gradovi trebali postati urbana središta koja će zadovoljiti sve potrebe radnoga čovjeka koji je nositelj razvoja novoga socijalističkog društva. Takvi idealni gradovi trebaju zadovoljiti osnovne potrebe radnika - pravo na rad i stanovanje, a potom i njegovu potrebu za kvalitetnim korištenjem slobodnoga vremena, koja se ogleda u konzumaciji kulture i rekreaciji. ${ }^{9}$ U praksi, socijalistički gradovi nakon Drugoga svjetskog rata ne zadovoljavaju ni osnovnu potrebu za stanovanjem, a kvaliteta postojećega stanovanja je niska. Dijelom je razlog ratno razaranje, dijelom skroman prijeratni standard, ali i intenzivna industrijalizacija koja je uzrokovala deruralizaciju, odnosno potaknula preseljenje stanovništva iz sela u gradove. Prvotno se stambeni fond popunjavao nacionalizacijom i konfiskacijom imovine te

\footnotetext{
5 Vidi: ANTOLIĆ, „Regulacioni plan i direktivna regulaciona osnova Zagreba”; Zagreb: direktivna regulatorna osnova Zavoda za urbanizam NOGZ 1953.; Urbanistički program grada Zagreba: smjernice za razvoj; Generalni urbanistički plan grada Zagreba: elaborat; Generalni urbanistički plan grada Zagreba: sažetak.

FRANKOVIĆ, „Urbanističko planiranje Zagreba od 1945. do 1985.”, 85-87.

DAKIĆ, „Generalni urbanistički plan grada Zagreba”, 6.

BARA, „Modernizacija urbanoga života u Hrvatskoj”, 28.

Isto, 17.
} 
proizvodnjom tipiziranih montažnih stambenih objekata, a potom se prešlo na masovnu stambenu izgradnju, prepoznatljivu po planskim radničkim naseljima i dijelovima gradova koji se nazivaju „spavaonice” (Novi Zagreb). Neslužbena politika državnih i gradskih vlasti, koja je poslije postala jedno od obilježja socijalističke stanogradnje, dopuštanje je gradnje privatnih bespravnih objekata, najčešće prizemnica. Šezdesetih i sedamdesetih godina XX. stoljeća bespravna je izgradnja činila oko $50 \%$ ukupne izgradnje. ${ }^{10}$

Javne politike u Jugoslaviji (Hrvatskoj) donosile su se na okomitoj razini (dimenziji), odnosno na formalnoj ili državnoj razini, te na vodoravnoj, odnosno neformalnoj razini, koju čine razni nedržavni akteri. Na vodoravnoj razini prisutno je djelovanje širokoga kruga sudionika (interesenata), koji mogu djelovati samostalno ili biti dio organizacije, ali oni djeluju izvan strogo definirane hijerarhijske vlasti. ${ }^{11} \mathrm{U}$ slučaju grada Zagreba to je značilo da okomitu dimenziju čine republičke vlasti, gradonačelnik i Skupština grada Zagreba, gradski odbori te, zbog izostanka pluralizma, Komunistička partija Hrvatske (poslije: Savez komunista Hrvatske), a vodoravnu dimenziju strukovne i istraživačke organizacije, fakulteti te razne gradske institucije. U nekim državnim resorima prostora za sukreiranje javne politike jednostavno nije bilo - to su uglavnom resori vanjske politike, sigurnosnih politika, obrambene politike, politika javnoga reda i mira i ostalih politika iz uskoga djelokruga države, a najviše je prostora bilo u onim područjima u kojima političke elite nisu nazirale prijetnju svojem autoritetu. Riječ je uglavnom o područjima socijalnih politika koje se ogledaju u politikama urbanizacije i prostornoga uređenja te stambenoj, komunalnoj i zdravstvenoj politici. ${ }^{12}$

Koliko je zagrebačkim gradskim vlastima važan svaki prijedlog urbanističkoga programa i generalnoga urbanističkog plana vidi se po tome da je na sjednicama gradske skupštine generalni urbanistički plan uvijek prva točka dnevnoga reda ili mu je čak posvećena cijela sjednica. Važnost urbanističkoga planiranja vidi se i po tome što svaki prijedlog generalnoga urbanističkog plana i urbanističkoga programa prati sveobuhvatna rasprava u stručnim komisijama Skupštine grada Zagreba, stručnim organizacijama, društveno-političkim organizacijama i zborovima građana, koja traje i po nekoliko godina.

\section{Metodologija}

U istraživanju su kao primarni izvori korišteni generalni urbanistički planovi Zagreba (regulatorne osnove), jedan program urbanističkoga razvoja

\footnotetext{
Isto, 18-21.

Isto, 14-15.

Isto, 17.
} 
i dva prijedloga urbanističkoga razvoja: Vlado Antolić, „Regulacioni plan i direktivna regulaciona osnova Zagreba”; Zagreb: direktivna regulatorna osnova Zavoda za urbanizam NOGZ 1953.; Urbanistički program grada Zagreba: smjernice za razvoj; Generalni urbanistički plan grada Zagreba: elaborat; Generalni urbanistički plan grada Zagreba: sažetak. Kao sekundarna građa korišten je arhivski fond Narodni odbor grada Zagreba koji se čuva u Državnom arhivu u Zagrebu te objavljena literatura kao tercijarni izvori.

Analizom primarnih izvora ustanovljeno je kakvi su bili planovi stambenoga razvoja Zagreba u samim generalnim urbanističkim planovima (regulatornim osnovama), programu urbanističkoga razvoja i prijedlozima niže razine. Analizom arhivske građe dobio se uvid u tijek priprema i rad na urbanističkom razvoju, a u objavljenoj literaturi iščitava se koliko je bila uspješna realizacija planova urbanističkoga razvoja Zagreba te kakvo je mišljenje struke o urbanom razvoju grada i stambenoj politici koja se provodila na temelju urbanističkih planova i programa. Na osnovi prikupljenih podataka zaključno se donosi komparacija prijedloga i prihvaćenih urbanističkih planova te njihove realizacije. Problem pri analizi jest činjenica da su planovi i prijedlozi planova nastajali u dužem periodu te je time i njihov pristup problematici drugačiji, i zbog promjene politike i zbog promjene u samoj urbanističkoj struci, što je vidljivo iz fokusa njihova interesa, kao i iz sadržajnosti planova. Zato komparacija nije bila moguća u svim segmentima, nego je napravljena parcijalno.

\section{Zagrebačka stanogradnja u prijedlozima iz 1949. i 1953.}

Inženjer arhitekture Vladimir (Vlado) Antolić, u to vrijeme direktor Urbanističkoga instituta Narodne Republike (NR) Hrvatske u Zagrebu, zajedno sa suradnicima, inženjerima Vladimirom Franzom i Aptullom Halilibrahimovom te arhitektima Stjepanom Hribarom i Ivanom Layem, 1949. objavljuje prvi poslijeratni prijedlog urbanističkoga razvoja Zagreba naziva „Regulacioni plan i direktivna regulaciona osnova Zagreba”. ${ }^{13}$ Prijedlog je objavljen u časopisu Arhitektura, a poslan je i u druge stručne časopise te Narodnom odboru grada Zagreba (NOGZ). ${ }^{14}$ Iako NOGZ nije prihvatio prijedlog iz 1949., on se ipak koristio kao osnova za investicije koje su iznosile 150 do 160 milijuna dinara, a uključivale su provedbu „elektrifikacione mreže na osnovu aproksimativnih proračuna i podataka naših ustanova, zatim izgradnja javnih, industrijskih i stambenih objekata". ${ }^{15}$ Godine 1953. objavljen je djelomični prijedlog

\footnotetext{
ANTOLIĆ, „Regulacioni plan i direktivna regulaciona osnova Zagreba”, 5. HR-DAZG-NOGZ-37.3 SIT, kut. 33, Zapisnik 14. studeni 1952., 2.

Isto, 3 .
} 
regulatorne osnove Zagreb: direktivna regulatorna osnova Zavoda za urbanizam NOGZ 1953.

Prijedlog iz 1949. napravljen je u Urbanističkom institutu NR Hrvatske, a prijedlog iz 1953. radit će Zavod za urbanizam NOGZ-a, prethodnik Urbanističkoga zavoda. Ono što povezuje ta dva prijedloga upravo je Vlado Antolić, koji 1949. vodi Urbanistički institut NR Hrvatske, a do lipnja 1953. Zavod za urbanizam NOGZ-a. Objava prijedloga iz 1953. dugo se čekala te je u više navrata požurivana njegova izrada. Antolić na sastanku Savjeta za komunalne poslove NOGZ-a na sjednici održanoj 14. studenog 1952. brani dugotrajnost izrade prijedloga, ali iznosi i da se na „Regulatornom planu grada Zagreba kao cjelini” počelo „sistemski raditi” tek 1947. jer „1945. i 1946. bili smo zauzeti obnovom naših popaljenih sela i ratom oštećenih gradova”. ${ }^{16}$ Iako prijedlozi iz 1949. i 1953. nisu prihvaćeni, oni će se svejedno idućih godina „parcijalno koristiti za provedbu 'Društvenog plana'". ${ }^{17}$

Prijedlog regulatorne osnove Zagreb: direktivna regulatorna osnova Zavoda za urbanizam NOGZ 1953. dostupan je u Nacionalnoj i sveučilišnoj knjižnici te u Knjižnicama grada Zagreba samo u obliku jedne zemljopisne karte veličine $71 \times 99 \mathrm{~cm}$. U Državnom arhivu u Zagrebu, u građi Zavoda za urbanizam NOGZ-a, kao i u samome fondu NOGZ-a, nije pronađen dokument istoga naziva, odnosno dokument ili prijedlog regulatorne osnove iz 1953. godine. Prema izvještaju Savjeta za komunalne poslove NOGZ-a o radu u 1954. proizlazi da je prijedlog regulatorne osnove prikazan samo u obliku mapa (odnosno grafičkih predložaka): „Direktivni Regulacioni plan prikazan je u mapama 1 : 5000 radi tekućih potreba i detaljnih razrada regulacije." ${ }^{18}$ Dodaje se da su do dana podnošenja izvještaja (ne samoga prijedloga direktivnoga regulacionog plana), odnosno do 16. studenog 1954., napravljene i „parcijalne osnove” i „studije” za pojedina naselja te „detaljne osnove pojedinih predjela grada”, ali se ne navodi kojih predjela. „Parcijalne osnove” napravljene su za stambena naselja „na Feren[š]čici, u Dubravi i Volovčici; za regulaciju predjela Ulice Socijalističke Revolucije i Ružmarinke, te osnova za Sigečicu”. Završene su i „studije” za „regulaciju predjela Ilice, Kačićeve i Primorske ulice: za regulaciju predjela Martićeve i Laginjine ulice / 3 alternative /; za regulacioni plan Stenjevca, prema direktivnoj osnovi $1: 10.000$, u vezi čega je projektirano produženje Bolničke c." ${ }^{19}$ Slijedom iznesenoga proizlazi da tekst Zagreb: direktivna regulatorna osnova Zavoda za urbanizam NOGZ 1953. ne postoji, nego

\footnotetext{
Isto, 2 .

BAKAL, „30 godina Urbanističkog zavoda grada Zagreba”, 3-4.

HR-DAZG-NOGZ-37.3 SIT, kut. 33, Izvještaj Savjeta za komunalne poslove Narodnog odbora grada Zagreba o radu u 1954. godini, 16. studeni 1954., 9.

19 Isto, 9-10.
} 
postoji samo mapa (karta ili grafički predložak) Zagreba te studije i detaljne osnove za pojedine ulice, naselja i dijelove grada.

Da su prijedlog iz 1949. i ono što se u literaturi navodi kao prijedlog iz 1953. dio jedne cjeline vidimo iz teksta prijedloga iz 1949. godine: „Prikazani radovi i rješenja čine dio rada oko regulacije Zagreba za predviđeni period u budućnosti od oko 30 godina. Rad je u toku, te se može smatrati kao studij za izradu konačne direktivne osnove. Na temelju tih studija trebat će izraditi još etapne generalne i detaljne planove za provedbu." ${ }^{20}$ Potvrdu da su prijedlozi iz 1949. i 1953. jedna cjelina nalazimo i u govoru ing. Vlade Antolića na sjednici Savjeta za komunalne poslove NOGZ-a o stanju u Zavodu i radovima na regulatornoj osnovi. Iz Antolićeva se izlaganja saznaje dotadašnji tijek priprema za izradu regulatorne osnove te da je prijedlog iz 1949. pripremna radnja za prijedlog iz 1953. godine. Nakon prijedloga iz 1949. najprije su 1950. napravljene i tiskane mape Regulatornoga plana u mjerilu $1: 50.000$ i $1: 100.000$, a zatim mape užega Zagreba u mjerilu $1: 5000 .{ }^{21}$

Narodni odbor grada Zagreba dao je na prijedlog regulatornoga plana „niz opravdanih, ali i neopravdanih primjedaba”, od kojih je dio prihvaćen te su napravljene korekture, angažirani su razni stručnjaci, od kojih su mnogi i sveučilišni profesori. ${ }^{22} \mathrm{U}$ drugoj polovini 1953. gradu Zagrebu trebao je biti iznesen (predložen) dokument Zagreb: direktivna regulatorna osnova Zavoda za urbanizam NOGZ 1953., na temelju kojega se trebala izraditi generalna regulatorna osnova, odnosno generalni urbanistički plan (GUP), međutim iz dokumenata NOGZ-a proizlazi da završni dokument nije predočen NOGZ-u na razmatranje. Kako je spomenuto, ono što se u literaturi navodi kao prijedlog naziva Zagreb: direktivna regulatorna osnova Zavoda za urbanizam NOGZ 1953. jest spomenuta karta iz 1953. i niz karata (mapa) koje su izrađivane za pojedine dijelove grada i ulice.

U prijedlogu iz 1949. ističe se da unatoč potrebnim izmjenama grad treba ostati ,jedinstveno djelo”, a osnovno mjerilo „za gledanje i ocjenu svih problema i njihova rješavanja treba da bude - čovjek”. ${ }^{23}$ Nadalje, govori se da „postojeća stambena kriza i sadašnja poteškoća oko osiguranja za gradnju potrebnog materijala i radne snage" ima presudnu ulogu u razvoju grada, a time i u izradi i provedbi plana. ${ }^{24}$ Prijedlog iz 1949. stambenoj problematici pristupa sa stavom da se zbog pomanjkanja stambenoga prostora ne smiju „rušiti objekti u nereguliranim dijelovima grada, u t. zv. 'divljim naseljima”,

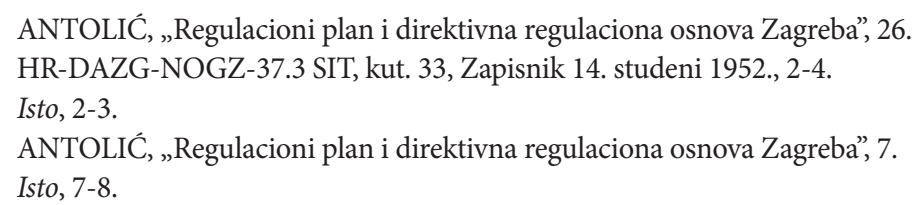


te da još nije vrijeme da se „pristupi asanaciji nehigijenski i gusto izgrađenih periferijskih naselja, te na taj način otpada u gradu velik broj površina koje bi trebalo upotrijebiti za izgradnju grada”. Takvim pristupom sama struka daje prešutno odobrenje za ilegalnu izgradnju i očuvanje „divljih naselja”, koja su specifična za rubne dijelove Zagreba sve do današnjega dana. Nadalje, zbog nedostatka zemljišta potrebnog za nova naselja unutar grada predlaže se pripajanje slobodnih terena izvan tadašnje granice grada - „da se pođe sa naseljima izvan sadašnjega grada ili daleko na njegovu periferiju”. ${ }^{25}$

Problem razvoja grada u širinu prepoznat je već u prijedlogu iz 1949., ali zbog objektivnih razloga, pomanjkanja „visokovrijednoga” građevnog materijala, bila je nužna izgradnja niskih stambenih objekata, „koji zahtijevaju ogromne nove površine na periferiji grada”. Već je tada bilo jasno da će se grad time razviti u širinu, što će donijeti neke prednosti, ali i velike nedostatke, koji su prije svega ekonomske prirode i odnose se na troškove izrade i održavanja velikih površina cesta i instalacija te na izazov (nemogućnost) prometnoga povezivanja preširokoga grada. ${ }^{26}$ Zbog neizbježnosti razvoja grada u širinu i potrebe smještanja velikih industrijskih postrojenja izvan grada predlaže se isprepletanje grada mrežom zelenila. Kao pretpostavka je uzeto da će grad ekonomski jačati, što će dovesti do povećanja životnoga standarda i stambenih norma, odnosno do povećanja prosječne stambene površine po osobi. To će u drugoj etapi iziskivati gradnju novih stanova, odnosno većih stambenih objekata, što će se omogućiti asanacijom centralno smještenih postojećih naselja u gradu kao što su Trnje, Trešnjevka i Kustošija. ${ }^{27}$

U prijedlogu iz 1949. kaže se da uži dio grada tada ima oko 280.000 stanovnika, širi dio oko 320.000, a gradska površina iznosi oko 6000 ha. Predviđa se da će Zagreb za trideset godina, dakle početkom osamdesetih, imati između 500.000 i 600.000 stanovnika, a površina stambenih naselja zauzimati 3000 ha, i procjena je da će gustoća naseljenosti biti od 100 do 300 stanovnika/ha, odnosno prosječno 150 stanovnika/ha. ${ }^{28}$ Razvoj Zagreba predviđen je „lepezasto" u smjeru istok-zapad te prema Savi. Predviđene su dvije glavne industrijske zone, na istoku i zapadu grada, u sredini grada stambena naselja, a u centru upravno-kulturna zona. Previđen je plovni kanal i luka s jugoistočne strane grada, teretna željeznica obilazila bi grad s juga, a putnički prijevoz prolazio bi kroz grad „nadvišeno”. Autocesta bi obilazila grad s juga, oko gra-

Isto, 8 .

Isto.

Isto.

Isto, 9 . 
da bi išla „kružna cesta”, a za sjeverni izlaz iz grada predviđen je tunel ispod Sljemena. ${ }^{29}$

Prijedlogom plana grad je podijeljen na pet zona ili dijelova: I. Stambena zona, II. Industrijska zona, III. Zona opskrbe i raspodjele, IV. Zona uprave i kulture i V. Zona rekreacije. Stambenu zonu činila bi dva dijela: „stari postojeći dio grada”, koji je predviđen za stanovanje i „za poslovni dio (city)”, te drugi, koji se dijeli na „a) Postojeća stambena naselja koja treba sanirati, postepeno pregraditi i regulirati. To su naselja južno od željeznice: Trnje, Trešnjevka Kustošija itd” i „b) Projektirana buduća nova stambena naselja. To su naselja - zapadno, u smjeru Stenjevca i - istočno, u smjeru Sesveta i - južno, od rijeke Save" ${ }^{30}$

Prema prijedlogu iz 1949., veličina stambenoga naselja određena je prometnom mrežom koja ga okružuje, gdje je razmak između prometnica određen na 400-600 m. Stambena naselja predviđena su kao zaokružene cjeline u kojima se živi „samostalnim životom”, što znači da se naselje lokalno opskrbljuje svakodnevnim potrepštinama, da ima školu, sedmoljetku, igralište, dječje jaslice, dječji vrtić s igralištem te po mogućnosti svoj lokalni manji sportsko-rekreacijski centar itd. Broj stanovnika određen je prema broju djece koja polaze sedmoljetku, što znači da bi naselja trebala imati od 2000 do 10.000 stanovnika. $^{31}$

Narodni odbor grada Zagreba odbija prijedlog iz 1949. u prvom redu iz dva razloga: ne prihvaća koncepciju željezničkoga čvora i odbija širenje grada prema jugu, odnosno „prelazak” Save. U literaturi se navodi da su isti razlozi bili i za odbijanje prijedloga iz 1953., međutim u dokumentima nema potvrde da je prijedlog iz 1953. uistinu podnesen NOGZ-u, a poglavito da je razlog odbijanja bilo širenje Zagreba na jug, odnosno „prelazak” Save. Naime, širenje Zagreba na jug i prelazak Save počinje već 1953. i iz dokumenata saznajemo da se na tome radilo i idućih godina, a dokument „Investicioni program za asanaciju terena južno od rijeke Save u god. 1955. / Podbrežje / I. etapa” opisuje radove izvođene 1953. i 1954. te planove za novu etapu radova u 1955. godini. U dokumentu stoji da direktivna regulatorna osnova grada Zagreba predviđa „Širenje grada na jug preko rijeke Save”. ${ }^{32}$ Dakle, argument da je prijedlog iz 1953. odbijen zbog prelaska Save nije točan. Iz zapisnika sastanka Savjeta za komunalne poslove NOGZ-a održanog 2. srpnja 1953. doznaje se da su radovi već počeli i da postoji problem s eksproprijacijom privatnoga zemljišta preko

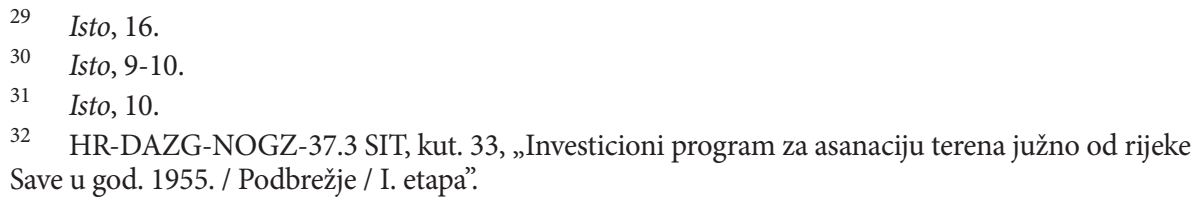


kojega će ići cesta koja će voditi do novoga velesajma. ${ }^{33} \mathrm{Na}$ zajedničkoj 14. sjednici Gradskoga vijeća i Vijeća proizvođača NOGZ-a održanoj 28. prosinca 1953. donijet je zaključak kojim se ovlašćuje predsjednika Narodnoga odbora Većeslava Holjevca ${ }^{34}$ da se u Beogradu konzultira s članovima Saveznoga izvršnog vijeća u pitanju „pristupanja lokaciji izgradnje novog kao i privremenog proširenja postojećeg velesajma preko Save, te novo nastale situacije obzirom na izgradnju velesajma u Beogradu" ${ }^{35}$ Evidentno je da je Holjevac u iduća dva tjedna obavio potrebne konzultacije jer je na 21. sjednici Gradskoga vijeća NOGZ-a 12. siječnja 1954. upoznao Vijeće „sa situacijom u vezi izgradnje velesajma u Beogradu i razgovorima vođenim u tim pitanjima", te je na sjednici odlučeno da se mjesto novoga zagrebačkog velesajma određuje „suglasno predviđenoj regulatornoj osnovi grada Zagreba, na južnoj obali rijeke Save", a da NOGZ odmah pristupa „svim potrebnim radovima za izgradnju novog velesajma”. ${ }^{36}$ Dakle, iz citata proizlazi da je regulatorna osnova "predviđena”, a ne „predložena”. Početkom 1954. osnovana je Komisija za izradu generalne osnove grada Zagreba sa zadatkom korekcije prijašnjih prijedloga i donošenja konačnoga urbanističkog rješenja. Međutim, zbog nedostatka tehničke dokumentacije rad Komisije se otegnuo i ona na kraju nije ispunila svoj zadatak, ali su u međuvremenu realizirane neke postavke iz odbijenoga prijedloga. ${ }^{37}$ Tako je izgrađen prvi trak autoceste i Most slobode na Savi. ${ }^{38}$ Godine 1958. prihvaćeno je rješenje željezničkoga čvora, izrađen je i prihvaćen idejni plan i ostalih elemenata prometne mreže. Poslije su obrađene mreže igrališta i rekreativno-sportskih površina, obveznih škola, domova za zaštitu odraslih te mreža dječjih vrtića i jaslica. Prihvaćanjem i realizacijom tih elemenata programa „nastojalo se očuvati zemljišta predviđena za javne sadržaje i spriječiti da ne-

\footnotetext{
33 HR-DAZG-NOGZ-37.3 SIT, kut. 33, Zapisnik sastanka Savjeta za komunalne poslove NOGZ-a održanoga 2. srpnja 1953., 7.

34 Većeslav Holjevac, političar (Karlovac, 22. kolovoza 1917. - Zagreb, 11. srpnja 1970.), od 1952. do 1963. predsjednik NOGZ-a i član Sekretarijata Gradskoga komiteta Saveza komunista Hrvatske. Najzaslužniji za proširenje Zagreba južno od Save, prenošenje Zagrebačkoga velesajma u Novi Zagreb, kao i za prometni, infrastrukturni, građevinski i urbanistički razvoj Zagreba. Vidi: „Holjevac, Većeslav".

35 HR-DAZG-NOGZ-37.1 SPT, knj. 74, 14. zajednička sjednica Gradskog vijeća i Vijeća proizvođača Narodnog odbora grada Zagreba održana 28. prosinca 1953., 428.

36 Službeni glasnik Narodnog odbora grada Zagreba (Zagreb), god. VIII, 3. 2. 1954., br. 2-4, 20-21.

37 Članovi Komisije za izradu generalne osnove grada Zagreba: a) predsjednik, ing. Rikard Marasović; b) članovi - po jedan predstavnik iz svakoga savjeta NOGZ-a; c) ostali članovi: iz Društva arhitekata Hrvatske - ing. Josip Seissel; iz Komande garnizona Zagreb - major Ivan Kaleb; iz Uprave za vodoprivredu NRH - ing. Ivan Milković; iz Društtva ekonomista Hrvatske - ing. Ivan Krešić; iz Društva građevinskih inžinjera i tehničara NRH - ing. Nikola Horvat; te iz Direkcije željeznica - ing. Roman Jelovica. Isto, 12.

38 Urbanistički program grada Zagreba: smjernice za razvoj, 10.
} 
planska individualna izgradnja, uvjetovana snažnom migracijom stanovništva u Zagreb" uzurpira površine predviđene za spomenute sadržaje. ${ }^{39}$

U onome što se smatra dijelom iste cjeline - prijedlogu iz 1949. i kartama iz 1953. - iznose se projekcije broja stanovnika u trideset godina i podaci o gustoći stanovništva u gradu, ali nedostaje projekcija broja stanova koje je potrebno izgraditi u tom periodu, izostavljeni su podaci o gustoći po stambenoj jedinici, veličini stanova i površini stana po stanovniku. U odnosu na ostale programe i planove, prijedlog iz 1949. i karte (mape) iz 1953. skromniji su u iznošenju podataka i projekcija, pa je time i njihova mogućnost komparacije manja.

Zagrebačka stanogradnja u programu iz 1965.

Nakon gotovo dva desetljeća rada na urbanističkom planu Zagreba 1963. Urbanistički zavod predstavlja dokument niže razine od GUP-a (plana), odnosno urbanistički program. Riječ je o dokumentu koji se dugo čekalo i oko kojega su vođeni brojni sporovi. Nakon dvogodišnje rasprave u stručnim komisijama Skupštine grada Zagreba, ${ }^{40}$ stručnim organizacijama, društveno-političkim organizacijama i zborovima građana program će 7. srpnja 1965. biti prihvaćen na zajedničkoj sjednici svih vijeća Skupštine grada Zagreba. ${ }^{41} \mathrm{Naj}$ zaslužniji za njegovu izradu tadašnji je direktor Urbanističkoga zavoda inženjer Zdenko Kolacio. Radi se o dokumentu na 73 stranice, dakle znatno većem od prijedloga iz 1949., koji je napisan na 25 stranica, ujedno i bogatijem podacima te planski razrađenijem. Razlog zašto taj dokument nije još i veći leži u činjenici da su njegovu izradu pratili brojni tehnički problemi; naime, nedostajala je tehnička podloga i dokumentacija - nove geodetske karte, geotehnički i hidrološki podaci, podaci o klizištima, postojećoj komunalnoj mreži i dr. ${ }^{42}$

Urbanističkim programom grada Zagreba iz 1965. predviđeno je da se u trideset godina izgradi 281.000 novih stambenih jedinica s ukupnom površinom od $16.150 .000 \mathrm{~m}^{2}$ i procjenjuje se da će broj stanovnika na užem gradskom području do 1993. narasti na 950.000, a 1961. bilo ih je 460.000. ${ }^{43}$ Prema podatku iz 1960., postojeći stambeni fond iznosi oko 110.000 stanova sa 5,1 milijun $\mathrm{m}^{2}$ stambene površine. U programu je predviđeno da se zadrži 63,2\% postojećega stambenog fonda, a 36,8 \% potrebno je zamijeniti, uz napomenu

\footnotetext{
39 Isto, 3.

40 Skupština grada Zagreba pravni je sljednik Narodnoga odbora grada Zagreba. Ustavnim promjenama 1963. dolazi do administrativno-teritorijalne reorganizacije.

41 Generalni urbanistički plan grada Zagreba: prva projekcija, 7.

42 Isto, 7.

43 Urbanistički program grada Zagreba: smjernice za razvoj, 4, 7, 20, 46.
} 
da ovdje nije zabilježena „divlja gradnja” nakon 1960. godine. ${ }^{44} \mathrm{U}$ dijelu o stanovanju, komunalijama i objektima društvenoga standarda iznesen je podatak da $75 \%$ postojeće stambene izgradnje čine stambene zgrade prizemnice i jednokatnice. ${ }^{45}$ Karakteristika zagrebačkoga stambenog fonda stanovi su s malim brojem soba ( $86 \%$ jednosobnih i dvosobnih), mala prosječna veličina stana (oko $47 \mathrm{~m}^{2}$ ), s prosječno 2,8 članova domaćinstva, gdje na jedan stan dolazi 3,8 stanovnika, što znači da na jednoga stanovnika dolazi oko $11,4 \mathrm{~m}^{2}$ stambene površine, a u jednoj sobi živi 2,5 osoba. ${ }^{46} \mathrm{U}$ trideset godina predviđeno je i povećanje normativa stambene površine na oko $20 \mathrm{~m}^{2}$ po stanovniku te smanjenje broja osoba po sobi na $1,2 .{ }^{47}$ Programom je predviđeno da bi za trideset godina Zagreb imao 350.000 stanova ukupne površine oko $19.400 .000 \mathrm{~m}^{2}$. Od predviđenih 350.000 stanova najviše bi bilo trosobnih (26\%) te garsonijera i posebnih soba (26\%), potom dvosobnih $(18,5 \%)$, jednosobnih $(12,5 \%)$, četverosobnih $(11,9 \%)$ i s pet i više soba $(5,1 \%)$. Gledano po površini, najviše bi prostora zauzimali trosobni stanovi $(32,9 \%)$, potom dvosobni $(18,4 \%)$, četverosobni $(18,3 \%)$, garsonijere i posebne sobe $(11,7 \%)$, stanovi s pet i više soba $(9,7 \%)$ te jednosobni $(9 \%){ }^{48}$

Programom iz 1965. predviđeno je „uz asanaciju i rekonstrukciju postojećih stambenih zona" povećati ukupnu stambenu zonu s dotadašnjih 2600 ha na preko 5200 ha, odnosno to je „15,5 \% površine urbanističkog zahvata”. ${ }^{49}$ Program izgradnje trebao je obuhvatiti „četiri tipična dijela grada”: „najnoviji dio na obali Save (1) s minimalnim rekonstrukcijama područja; između Save i željezničke pruge (2) s opsežnijim rekonstrukcijama i bitnim kvalitativnim i kvantitativnim promjenama; zatim dio grada sjeverno od željezničke pruge (3) gdje se uglavnom ne predviđa proširivanje stambenih zona. Sjeverni dijelovi grada na obroncima Medvednice (4) pretežno namijenjeni rekreaciji, djelomično su rezervirani za novu, kvalitetniju, uglavnom individualnu stambenu izgradnju (nizovi i drugi sistemi). ${ }^{50}$ Predviđeno je da se grad podijeli na petnaest urbanističkih stambenih dijelova („rajona”), sa 30.000 do 95.000 stanovnika, a svaki stambeni rajon bi imao svoj centar koji bi osiguravao potrebe stanovništva. Pojedini rajon imao bi od tri do pet stambenih zajednica, a svaki rajonski centar bio bi povezan javnim gradskim prijevozom. ${ }^{51}$

Isto, $44-45$.
Isto, 44.
Isto, $45-46$.
Isto, 46.
Isto, 46.
Isto, 45.
Isto.
Isto, 68.


U programu je istaknuta neujednačenost karaktera stambenih zona i iskorištavanja zemljišta unutar njih jer odstupaju od urbanističke i ekonomske opravdanosti gustoće naseljenosti i stambene izgradnje u gradu. Koliko su stambene zone neujednačene vidi se iz podatka da gustoća stanovništva varira od 20 stanovnika/ha u perifernim područjima do 950 stanovnika/ha u starom centru. ${ }^{52}$ Rješenje toga problema, odnosno racionalnije iskorištavanje zemljišta, pronalazi se u povećanju prosječne gustoće od 172 stanovnika u postojećim stambenim zonama (bez pratećih objekata) na 185 stanovnika/ha s pratećim objektima. Predviđeno je da bi se tim prijedlogom tijekom trideset godina donekle ujednačila gustoća u stambenim zonama na razinu od 90 do 300 stanovnika/ha. ${ }^{53}$

Programom iz 1965. predviđeno je znatno poboljšanje kvalitete komunalne infrastrukture, koja je najslabija u pogledu opskrbe plinom, a najpovoljnija u pitanju električne mreže. Plinom je 1961. opskrbljeno 30,9 \% stanovnika, na vodovod je spojeno 59,2 \%, na kanalizaciju 68,2 \%, odvoz smeća koristi $79,3 \%$, električnu energiju ima 99,5 \% stanovnika Zagreba, međutim slab je njezin kapacitet jer je $60 \%$ mreže dotrajalo. Broj telefonskih priključaka 1961. bio je 2,96 na 100 stanovnika, a do 1965. planirano ga je povećati na 6,1 na 100 stanovnika. ${ }^{54}$ Urbanističkim programom predviđeno je da se gotovo cijelo gradsko područje spoji na dvije tada postojeće toplane (Toplana Zagreb I na zapadu i Toplana Zagreb II na istoku) te da se time osigura toplinska energija i topla voda za stanovništvo, javne ustanove i industriju. Zanimljivo je da se ostavlja prostor, ako se pokaže potrebnim, za gradnju lokalnih toplana, ali i „atomske centrale” na području koje obuhvaća budući generalni urbanistički plan, dakle unutar gradskoga područja. ${ }^{55}$

\section{Zagrebačka stanogradnja u planu iz 1971.}

Prvi poslijeratni GUP grad Zagreb dobiva krajem 1971. godine. Prijedlog plana iznesen je 1970., iste godine objavljena je i izmijenjena verzija, a Skupština grada Zagreba prihvaća ga 1971. godine. ${ }^{56}$ Direktor Urbanističkoga zavoda i tada je Zdenko Kolacio, a „šef grupe” koja je izradila plan arhitekt Josip Uhlik. ${ }^{57} \mathrm{U}$ izradi plana sudjelovale su razne institucije, privredne organizacije i

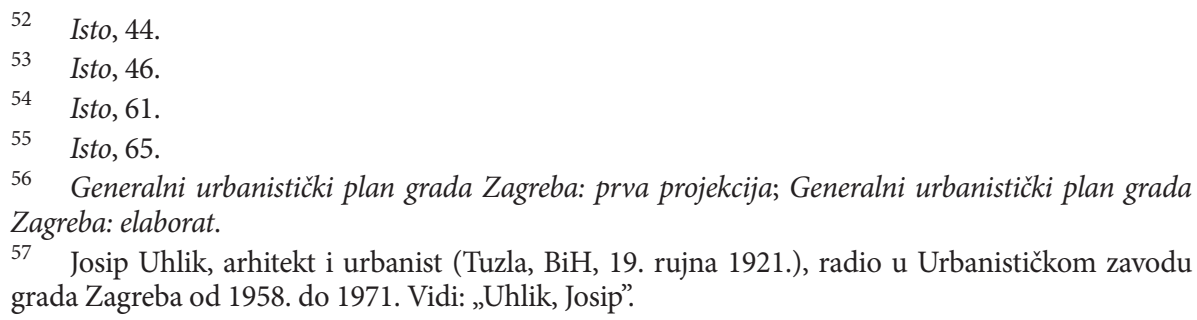


pojedini stručnjaci - Centar za ekonomski razvoj grada Zagreba, Urbanistički institut Socijalističke Republike (SR) Hrvatske, Ekonomski institut Zagreb, Zavod za urbanizam Arhitektonskoga fakulteta Sveučilišta u Zagrebu, Republički zavod za planiranje SR Hrvatske, Savezni zavod za urbanizam, komunalna i stambena pitanja Beograd, Institut građevinarstva Hrvatske, Urbanistički projektni zavod „Trešnjevka”, Branko Vasiljević, dipl. ing. arh. ${ }^{58}$ Generalni urbanistički plan iz 1971. počeo se izrađivati već 1965. nakon prihvaćanja $U r-$ banističkoga programa, odnosno samo se nastavilo raditi na cjelovitom planu razvoja Zagreba. Prilikom donošenja Urbanističkoga programa postavljene su osnovne smjernice i programski elementi za rad na GUP-u te izrađene brojne geodetske karte, hidrološke karte, karte klizišta, mreže komunalnih instalacija i druge karte, a sve radi sveobuhvatnoga GUP-a. ${ }^{59}$

Generalni urbanistički plan iz 1971. izrađen je na temelju Urbanističkoga programa koji je 1965. prihvatila Skupština grada Zagreba te je dopunjen novim spoznajama, a „njegovu je stvaranju naročito pridonijela istovremena izrada Prostornoga plana zagrebačke regije. Ovako usklađena akcija planiranja grada i regije dala je korisne rezultate". ${ }^{60}$ U GUP-u iz 1971. iznesena je konstatacija da je dotadašnja stambena politika bila neuspješna, odnosno da stambenom gradnjom nisu zadovoljene minimalne potrebe stanovanja $\mathrm{u}$ gradu, ali i da dolaze do izražaja međugeneracijske razlike i različiti životni stilovi, koji rezultiraju sukobima unutar obitelji, čime pitanje kulture stanovanja i stambene politike poprima i dublje sociološko značenje. ${ }^{61} \mathrm{U}$ tom GUP-u naglašava se potreba izbjegavanja izgradnje izričito stambenih, jednoznačnih naselja, „gdje se ništa ne događa”, i ističe potreba stvaranja gradskih prostora u kojima bi „mnogoznačnost gradskog života došla do izražaja”. ${ }^{62}$

Područje zahvata GUP-a iz 1971. znatno je prošireno u odnosu na Urbanistički program iz 1965., sa 33.900 ha na 45.900 ha, a razlog je uključivanje niza prigradskih naselja južno, zapadno i istočno od grada. Generalni urbanistički plan rađen je uz pretpostavku da će broj stanovnika Zagreba u idućih trideset godina, dakle do 2000., porasti sa 570.000 iz 1969. na milijun stanovnika, odnosno da će imati 376.000 domaćinstava. ${ }^{63}$ Stambene zone u Zagrebu zauzimaju 8500 ha, odnosno oko 18 \% površine. ${ }^{64}$ Gustoća naseljenosti u stambenim zonama trebala bi biti između 60 i 250 stanovnika/ha, prosjek za cijeli grad iznosio bi 120 stanovnika/ha. U odnosu na Urbanistički program iz 1965. gu-

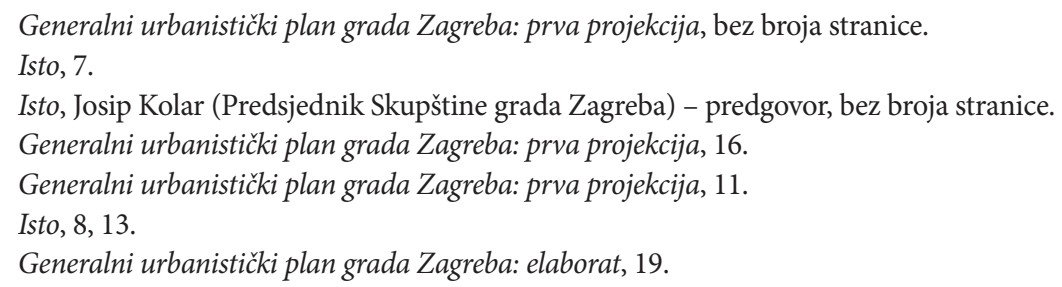


stoća se smanjuje, i to prvenstveno jer je proširen zahvat GUP-a i na zone niske gradnje te je povećan planirani standard stanovanja i stupanj motorizacije. ${ }^{65}$ Prema načinu gradnje, zone se dijele na one pretežno niske gradnje, zone miješane i zone visoke gradnje. Zone niske gradnje obuhvaćaju podsljemenski dio te periferna gradska naselja na zapadu, jugu i istoku. Zona s pretežno visokom gradnjom obuhvaća centralno područje - između Ilice, Vlaške i Petrove ulice na sjeveru i Save na jugu te područje južnoga Zagreba i centralni dio Dubrave. Zone miješane gradnje prate područja visoke gradnje, a nalaze se u predjelima Trešnjevke, Maksimira i Dubrave. ${ }^{66}$

Plan predviđa da će se stambena površina po stanovniku do 1985. povećati na $20 \mathrm{~m}^{2}$, a do 2000 . godine na $23-25 \mathrm{~m}^{2} .^{67}$ Generalni urbanistički plan predviđa i „osiguranje stana za svako domaćinstvo” te jedne sobe po osobi. Takvim planovima nastoji se dostići, kako navodi sam GUP, zapadnoeuropske standarde, gdje je još šezdesetih godina dosegnut standard od jedne sobe po jednoj osobi. ${ }^{68}$ Plan teži usklađivanju gradnje stambenih zgrada s pratećim objektima te omogućavanju njihove „optimalne organizacije”, što bi se postiglo uklanjanjem previsoke i preniske gustoće naseljenosti. ${ }^{69}$ Predlaže se optimalna gustoća naseljenosti između 70 i 100 stanovnika/ha u predjelima niske gradnje, od 100 do 200 stanovnika/ha u predjelima visoke i mješovite gradnje, a u zonama rekonstrukcije maksimalna gustoća naseljenosti iznosila bi 250 stanovnika/ha. Računajući srednju vrijednost iznesenih podataka, proizlazi da je za grad Zagreb predviđena prosječna gustoća od 162 stanovnika/ ha. Za zelene i slobodne površine predviđeno je $60 \%$ površine, a kao razlozi tako visoke zastupljenosti zelenih površina navode se higijensko-zdravstveni uvjeti i potreba za rekreativnim površinama, prostorom za igru predškolske i školske djece, za rekreaciju mladih i odraslih te za parkove. Površina cesta i parkirališnih mjesta ne bi trebala prelaziti $25 \%$ površine, čime je predviđena pokrivenost $70 \%$ potreba, a preostalo bi se riješilo podzemnim parkiralištima i višekatnim garažama. ${ }^{70}$

Do 2000. godine predviđeno je izgraditi 256.000 stambenih jedinica sa 16,8 do 18,4 milijuna $\mathrm{m}^{2}$ neto stambene površine. ${ }^{71}$ Predviđeno je da udio garsonijera i jednosobnih stanova padne sa $44,6 \%$ na $25,8 \%$, da se poveća udio trosobnih, četverosobnih i višesobnih stanova sa $17,9 \%$ na $44,2 \%$, a u perspektivi bi dvosobni stanovi trebali ostati najbrojniji, ali bi im udio trebao

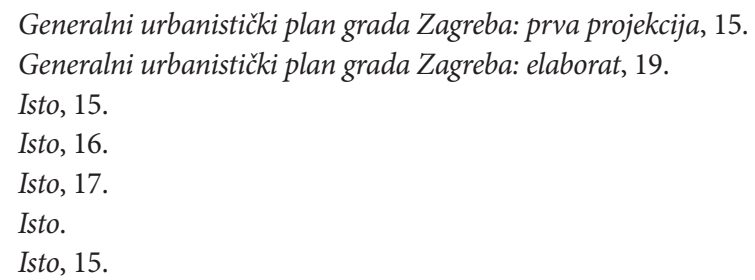


pasti sa $37,5 \%$ na $30,3 \%$. Prema GUP-u, samostalne sobe kao zasebne jedinice stanovanja više se nisu planirale graditi jer nisu udovoljavale osnovnim uvjetima stanovanja. ${ }^{72}$ Zbog podmirivanja stambenoga deficita do 1985 . većina stanogradnje usmjerena je na gradnju manjih (garsonijere i jednosobni) i srednjih (dvosobni) stanova, a zbog predviđenoga rasta standarda u kasnijim fazama predviđena je i gradnja većih stanova (trosobni, četverosobni i višesobni)..$^{73}$ Sumirani podaci pokazuju da GUP iz 1971. predviđa da će 2000. u Zagrebu prosječna površina stana iznositi $68 \mathrm{~m}^{2}$, da će na jednu osobu dolaziti $25 \mathrm{~m}^{2}$ površine, u jednom će stanu živjeti 2,7 osoba i na jedan će stan dolaziti 1,02 domaćinstva. $^{74}$

Prema riječima Aleksandra Bakala, ${ }^{75}$ GUP-om iz 1971. „zauzeti su suvremeniji stavovi o lociranju pojedinih sadržaja pa je izvedena potpunija integracija stanovanja, rekreacije i rada s tendencijom da se već u naseljima predvidi i stanovit broj radnih mjesta”. Planom je predviđeno rušenje oko 40.000 stanova s oko $1.800 .000 \mathrm{~m}^{2}$ stambene površine do 2000. godine. Bakal navodi i da je stambena izgradnja bila usmjerena „u područja koja omogućuju izgradnju uz sanaciju okolnih područja” te da se u realizaciji planova težilo izgradnji što većega broja stanova, pa se zbog toga „preskaču područja rekonstrukcije i 'proizvode' se mnoga nova naselja (Novi Zagreb). Prateći sadržaji se izostavljaju ili se grade sa znatnim zakašnjenjem. Javni prijevoz stagnira, a sredstva se ulažu u gradnju velikih prometnica". ${ }^{76}$

Generalni urbanistički plan iz 1971. uzima za pretpostavku da će nacionalni dohodak i standard rasti te na temelju toga predviđa izgradnju opremljenijih i većih stanova (73-85 $\left.\mathrm{m}^{2}\right)$. Osim većega broja stanova i veće površine, GUP predviđa i kvalitetniju izvedbu stanova i okoline jer je karakteristika dotadašnje gradnje bilo „pomanjkanje pratećih prostora u objektu, često i slaba izvedba, loša oprema, a naročito visoke cijene potenciraju probleme kolektivne stambene izgradnje". ${ }^{77}$

Koliko je realizirano od GUP-a iz 1971. saznajemo u ocjeni stanja objavljenoj pri izradi GUP-a iz 1986. godine. Publikacija Generalni urbanistički plan grada Zagreba: sažetak ocjenjuje da su se u „prostoru grada pojedine funkcije i područja grada razvijali vrlo neravnomjerno”; da je izgradnja grada pretežno usmjerena na izgradnju u novim gradskim područjima, a izostale su interven-

Isto, 16.

Isto, 16-17.

Generalni urbanistički plan grada Zagreba: prva projekcija, 18.

Aleksandar Bakal, urbanist i arhitekt (Nova Gradiška, 1. kolovoza 1929. - Zagreb, 22. siječnja 1997.), direktor Urbanističkoga zavoda grada Zagreba od 1972. do 1986. Vidi: „Bakal, Aleksandar”.

76 BAKAL, „30 godina Urbanističkog zavoda grada Zagreba”, 3-4.

77 Generalni urbanistički plan grada Zagreba: elaborat, 15-16. 
cije u postojećim gradskim područjima; da je tempo rekonstrukcije i sanacije znatno sporiji od GUP-om predviđenog; da je gotovo trećina svih gradskih površina po GUP-u namijenjenih zelenilu i sportsko-rekreacijskim zonama, koje su važne za kvalitetu života u gradu, zauzeta individualnom stambenom izgradnjom, i onom koja je postojala u vrijeme izrade plana i onom nastalom u međuvremenu, kao i znatnim površinama na kojima su eksploatirane mineralne sirovine; da nisu ostvarene pretpostavke GUP-a o zadovoljavanju standarda stanovanja, tj. da će do 1985. svako domaćinstvo imati stan; te da „umjesto planiranih sekundarnih centara, kao centar razvijala su se područja duž glavnih uličnih potez[a], naročito onih s javnim (tramvajskim) prometom". ${ }^{78}$

\section{Zagrebačka stanogradnja u planu iz 1986.}

Godine 1983. na 315 stranica tiskana je publikacija Generalni urbanistički plan: osnove generalnog urbanističkog plana Zagreba. Riječ je o osnovama GUP-a, odnosno o prvoj fazi izrade novoga GUP-a. Godine 1985. objavljen je GUP koji predstavlja drugu fazu izrade, a koji će biti prihvaćen 1986. godine. ${ }^{79}$ Prema riječima Aleksandra Bakala, revizija GUP-a iz 1971. započinje pripremnim radovima već 1978., a završava izradom i donošenjem Prostornoga plana grada Zagreba i generalnih urbanističkih planova Zagreba, Samobora, Velike Gorice, Sesveta i Zaprešića 1986. godine. ${ }^{80}$

U publikaciji iz 1983. osvrće se na GUP iz 1971. te se kaže da je bio dio „druge društvene i ekonomske realnosti”, da se radi o planu iz vremena „punog zamaha u izgradnji novog društva, pa je to neminovno plan novoga, novoga grada, temeljitih promjena, velike rekonstrukcije, Novog Zagreba i velikih sistema”. Generalni urbanistički plan iz 1971. opisuje se kao zamalo utopijski - „plan vjere u gotovo neograničene mogućnosti novog društva, zanemarivanja postojećeg grada i postojećih vrednosti”, te se zaključuje da on kao „plan budućnosti” nije mogao „biti bitno drugačiji”. ${ }^{81}$ Rečenicu nakon opisa GUP-a iz 1971. daje se opravdanje zašto novi GUP nema tako grandiozne planove - on je nastao „u novim uvjetima i spoznajama o mogućem”, ali ne zastupa filozofiju „siromaštva i bezizlaza”, nego se radi o planu „mjere, postupnosti i drugačijeg odnosa prema vrijednostima i stvaranju novih vrijednosti” ${ }^{82} \mathrm{Ge}-$ neralnim urbanističkim planom iz 1986. kritizira se prijašnji urbanizam jer je zanemarivao pitanja ljudske svakodnevice u gradu i umjesto toga bavio se

78 Generalni urbanistički plan grada Zagreba: sažetak, 4.

79 Generalni urbanistički plan: osnove generalnog urbanističkog plana Zagreba, 1; Generalni urbanistički plan grada Zagreba: sažetak.

80 BAKAL, „30 godina Urbanističkog zavoda grada Zagreba”, 4.

81 Generalni urbanistički plan: osnove generalnog urbanističkog plana Zagreba, 2.

82 Isto. 
„stručnim instrumentima planiranja 'za budućnost', 'perspektivama', 'rezervacijom prostora' i sl.”, a novim GUP-om naglasak se stavlja na poboljšanje kvalitete svakodnevnoga života. ${ }^{83}$ Prema analizama rađenim za GUP iz 1986., razdoblje od GUP-a iz 1971. do izrade novoga karakterizira nastavak neracionalnoga korištenja prostora s brojnim oblicima njegove privatizacije (bespravnom izgradnjom), zapostavljanje društvene vrijednosti neizgrađenih prostora i njihovo zapuštanje - poljoprivredne površine, parkovi i sl., te izgradnja u prostorima koji imaju širu društvenu vrijednost, kao i izgradnja predimenzioniranih objekata koji neracionalno koriste prostor. ${ }^{84}$

Novi GUP koristi podatke iz popisa stanovništva iz 1981., prema kojima Zagreb ima 657.706 stanovnika. Domaćinstava je te godine u Zagrebu bilo 233.052, s prosječno 2,82 člana. ${ }^{85}$ Predviđeno je da se do 2015. izgradi između 150.000 i 180.000 novih stanova. ${ }^{86}$ U GUP-u je uzeta pretpostavka da će u planiranom razdoblju, dakle do 2015., grad Zagreb imati 910.000 stanovnika (područje unutar zahvata GUP-a) te da će se zbog starenja stanovništva i niskoga nataliteta prosječna veličina domaćinstva smanjiti sa 2,82 na 2,75 članova, odnosno da će Zagreb imati 330.000 domaćinstava. ${ }^{87}$ Godine 1981. Zagreb ima 269.306 stanova ukupne površine $15.892 .903 \mathrm{~m}^{2}$; prema GUP-u iz 1986., to je povećanje broja stanova za 27 \% te povećanje stambene površine za $47,3 \%$. Iste godine prosječan stan imao je 2,16 soba, a prosječna površina stana iznosila je $59 \mathrm{~m}^{2}$. Prema strukturi stanova, 1981. bilo je najviše dvosobnih stanova $(41,4 \%)$, zatim jednosobnih $(25,3 \%)$, trosobnih $(21,4 \%)$, četverosobnih $(6,8 \%)$, sa pet i više soba $(2,8 \%)$ te posebnih soba $(2 \%) .{ }^{88}$

Kako je spomenuto, Zagreb 1981. ima ukupno $15.892 .903 \mathrm{~m}^{2}$ stambene površine. Do 2015. predviđena je izgradnja novih $11.700 .000 \mathrm{~m}^{2}$, što bi s predviđenim rušenjem i prenamjenom sveukupno iznosilo $27.000 .000 \mathrm{~m}^{2}$ stambene površine. Generalni urbanistički plan iz 1986. predviđa povećanje stambenoga prostora po stanovniku s tadašnjih $18,6 \mathrm{~m}^{2}$ na $22,5 \mathrm{~m}^{2}$, a za veličinu stanova predviđeno je povećanje sa $59 \mathrm{~m}^{2}$ na $64 \mathrm{~m}^{2} .{ }^{89} \mathrm{U}$ prijedlogu GUP-a izneseni su podaci da je 1981. na jednoga stalnog stanovnika grada dolazilo 18,6 $\mathrm{m}^{2}$ stambenoga prostora (1971. godine $14,7 \mathrm{~m}^{2}$ ), prosječno je jedna osoba u stanu imala $19,3 \mathrm{~m}^{2}$ prostora, a na jednu sobu dolazile su 1,4 osobe..$^{90}$

\footnotetext{
Generalni urbanistički plan grada Zagreba: sažetak, 9.

Generalni urbanistički plan: osnove generalnog urbanističkog plana Zagreba, 3.

Generalni urbanistički plan grada Zagreba: sažetak, 5.

Generalni urbanistički plan: osnove generalnog urbanističkog plana Zagreba, 232.

Generalni urbanistički plan grada Zagreba: sažetak, 10; Generalni urbanistički plan: osnove generalnog urbanističkog plana Zagreba, 232.

88 Generalni urbanistički plan: osnove generalnog urbanističkog plana Zagreba, 228.

89 Isto, 231.

$90 \quad$ Isto, 229.
} 
Plan je predviđao da se u stambenim naseljima građenim nakon Drugoga svjetskog rata intervenira dodavanjem radnih, poslovnih i drugih sadržaja, „tako da se oblikuju prostori gradskog izgleda, mješovitih namjena i s oblicima grada, posebno uzduž urbanih poteza kojima prolaze ili su planirane linije tramvaja (uređenje kolnika, drvoreda, oprema prostora i dr.)" ${ }^{11}$ Pri izradi GUP-a prihvaćenog 1986. pazilo se da se ne rade radikalne izmjene stanja, odnosno u novi se GUP nastojalo uključiti što veći broj postojećih stambenih objekata u zonama stanovanja, tj. zonama mješovite namjene, čime se nastojala smanjiti potreba rušenja postojećih objekata radi provedbe GUP-a. ${ }^{92}$

Slavko Dakić svjedoči da su generalni urbanistički planovi hrvatskih gradova „u pravilu bili metom oštrih kritika”, ali da izrada GUP-a iz 1986. nije „ponovila dramaturgiju prethodnih” te je „unatoč brojnih inovacijskih pokušaja, javna rasprava prošla uglavnom u znaku primjedbi najuže struke, a posebno su aktivne bile općinske uprave”. Plan je podržan u „općim orijentacijama i porukama”, a u javnoj raspravi osporavana su neka njegova operativna rješenja. ${ }^{93}$ Sama izrada plana odvijala se u „okolnostima posebno zaoštrene važnosti upravno-pravne komponente planiranja, izrazite podijeljenosti glede vrijednosnih orijentacijâ u urbanističkoj 'struci', partikularnih interesa koji svoj legalitet traže i u prostoru i koji su se plastičnije istakli zahvaljujući stanju u društvu, partikularizmu pojedinih strukâ čija se sektorska znanja i sve autonomnija sektorska pravna regulativa negativno prelama preko problematike grada kao sredine (koja se ne može niti opisati rječnikom i znanjem jedne struke), podijeljenosti na općine s vrlo različitom razvijenošću pa stoga i različitim problemima i motivacijama i sl." ${ }^{\prime 4}$

Najvažnija razlika između GUP-a iz 1986. u odnosu na GUP iz 1971., program iz 1965. i prijedlog iz 1949./1953. sužavanje je planskih granica urbanoga dijela Zagreba s prijašnjih 440 na $220 \mathrm{~km}^{2}$, odnosno na prostor između medvedničke šume i zagrebačke obilaznice. Naglasak se stavlja na afirmaciju principa „dovršenja” i „urbane obnove grada” umjesto na njegovo širenje na prirodno-ekološki vrijedne prostore Zagreba. Planom iz 1986. nastoji se zaštititi povijesne dijelove staroga Zagreba, kao i prirodu, odnosno prostor Medvednice koji je narušen prekomjernom gradnjom. Ističe se potreba afirmacije javnih gradskih prostora koji su se povijesno formirali kao prostori urbaniteta, umjesto u prethodnim dokumentima predlaganog širenja urbaniteta na nova gradska središta na „neuređenim i socijalno neprihvaćenim prostorima”. Jedan od problema koji je pratio Zagreb u njegovu razvoju nefunkcionalan je

\footnotetext{
Generalni urbanistički plan grada Zagreba: sažetak, 17.

PETRINJAK-ŠIMEK, „Programi zaštite prostora”, 10.

DAKIĆ, „Generalni urbanistički plan grada Zagreba”, 5.

Isto.
} 
javni gradski promet, a upravo se GUP-om iz 1986. daje potpora razvitku javnoga gradskog prometa, pri čemu se posebno redefinira uloga „kvalitetno prostorno pozicioniranog željezničkog čvora u korištenju za javni gradski i prigradski prijevoz" te se nastoji afirmirati biciklistički i pješački promet. ${ }^{95}$

Kao najveći nedostatak GUP-a iz 1986. izdvaja se neiskorištavanje velikih neizgrađenih prostora opremljenih svom gradskom infrastrukturom, kao što je prostor na Žitnjaku i prostori uz obilaznicu, te nedovoljno naglašavanje, odnosno izostanak „sustava urbanih pravila” kojima bi se onemogućila bespravna gradnja na urbanistički i strategijski važnim područjima kao što je onaj između željezničke pruge i Save. Kao najproblematičnije izdvojeno je neiskorištavanje rubnih gradskih prostora, poglavito onih koji su prometno dobro povezani poput prostora uz obilaznicu, nedovoljan naglasak na potrebi iskorištavanja urbanoga prostora između željezničke pruge i Save te problem prometne mobilnosti, odnosno nedovoljno apostrofiranje temeljnoga kriterija kretanja gradom. Valorizacija GUP-a iz 1986. napravljena krajem devedesetih godina posebno ističe da „planu uz prostornu nedostaju još dvije dimenzije: vremenska - terminska i instrumentalno-provedbena, te sustav kontrole urbanih promjena". ${ }^{96}$

\section{Komparacija}

Osnovni pokazatelji uspješnosti stambene politike i stambene izgradnje u nekom razdoblju jesu omjer broja izgrađenih stanova i njihove kvadrature s brojem stanovnika te stupanj zastupljenosti komunalne infrastrukture na pojedinoj stambenoj jedinici i kvaliteta same izgradnje. Širu sliku uspješnosti stambene politike dobivamo sagledavanjem kvalitete života u gradu, koju iščitavamo uvidom u gustoću naseljenosti, prometnu povezanost, zastupljenost zona rekreacije i zelenih zona te pozicioniranjem radnih mjesta u odnosu na mjesto stanovanja. Istraživani urbanistički planovi, program i prijedlog u svojem fokusu imaju upravo spomenuto, s dodatkom važnosti pozicioniranja industrije na karti grada.

Generalni urbanistički planovi iz 1971. i 1986. mnogo su razrađeniji i sadržajniji u odnosu na prijedloge iz 1949. i 1953. i program iz 1965., ali i prijedlozi i program sadržavaju sve osnovne elemente. Svi dokumenti odnose se na razdoblje od trideset godina, u kojemu na temelju procjene porasta stanovništva predviđaju razvoj grada, a u skladu s tim i investicije u pojedine sektore, pa i sektor stambene izgradnje. Istraživani dokumenti, iako fokusirani na istu pro-

95 DAKIĆ, BEDENKO, MATTIONI, Zagreb 2000+ Nova urbana strategija, 36.
96 Isto, 37. 
blematiku stambene izgradnje, ne iznose sve potrebne komparabilne podatke (vidi tablicu 1).

Tablica 1. Predviđeni razvoj Zagreba u urbanističkim planovima i prijedlozima

\begin{tabular}{|l|c|c|c|c|}
\hline Pokazatelji & $\begin{array}{c}\text { 1949./1953. } \\
\text { (do 1980.) }\end{array}$ & $\begin{array}{c}\text { 1965. } \\
\text { (do 1993.) }\end{array}$ & $\begin{array}{c}\text { 1971. } \\
\text { (do 2000.) }\end{array}$ & $\begin{array}{c}\text { 1986. } \\
\text { (do 2015.) }\end{array}$ \\
\hline Predviđeni broj stanovnika & 600.000 & 930.000 & 1.000 .000 & 910.000 \\
\hline $\begin{array}{l}\text { Predviđeno novih stanova } \\
\text { (u tisućama) }\end{array}$ & $\mathrm{x}$ & 281 & 256 & $150-180$ \\
\hline $\begin{array}{l}\text { Predviđena novoizgrađena } \\
\left.\text { površina ukupno (m }{ }^{2}\right)\end{array}$ & $\mathrm{x}$ & 16.150 .000 & $\begin{array}{c}16.800 .000- \\
18.400 .000\end{array}$ & 11.700 .00 \\
\hline $\begin{array}{l}\text { Predviđena stambena povr- } \\
\left.\text { šna po stanovniku (m }{ }^{2}\right)\end{array}$ & $\mathrm{x}$ & 20 & $23-25$ & 22,5 \\
\hline $\begin{array}{l}\text { Predviđena gustoća nase- } \\
\text { ljenosti (stanovnika/ha) }\end{array}$ & 150 & 185 & 162 & $\mathrm{x}$ \\
\hline $\begin{array}{l}\text { Predviđena veličina stana } \\
\left(\mathrm{m}^{2}\right)\end{array}$ & $\mathrm{x}$ & $\mathrm{x}$ & 68 & 64 \\
\hline
\end{tabular}

Od 1961. do 1981. dvadeset je ključnih godina za zagrebačku stanogradnju, kada je izgrađeno 55 \% zagrebačkoga stambenog fonda. Početkom osamdesetih godina većina objekata na širem gradskom prostoru u privatnom je vlasništvu (57,3 \% stanova i 55,5 \% površina). Društveno vlasništvo dominantno je u općinama Centar, Medvešćak, Novi Zagreb, Trešnjevka i Trnje, a u rubnim dijelovima grada dominira privatno vlasništvo. ${ }^{97}$

U Zagrebu je od 1945. do 1955. izgrađeno 9000 stanova, od kojih je najveći broj prizemnica (86,3 \%). ${ }^{98}$ Od 1956. do 1990. izgrađen je 210.261 stan, prosječne površine $59,6 \mathrm{~m}^{2}$, od čega je najviše dvosobnih (41,46\%) i jednosobnih (26,62 \%) (vidi tablicu 2). ${ }^{99} \mathrm{U}$ istraživanim dokumentima planiralo se povećanje izgradnje dvosobnih i trosobnih stanova, što se dijelom i ostvarivalo i dovodilo je do povećanja neto stambene površine po stanovniku, koja je 1961. iznosila $11,2 \mathrm{~m}^{2}$, 1971. porasla je na $14,7 \mathrm{~m}^{2}$, a 1981 . bila je $18,6 \mathrm{~m}^{2} .{ }^{100}$ Koliko su planovi GUP-ova iz 1971. i 1986. te programa iz 1965. bili preoptimistični u pogledu izgradnje stanova te time povećanja stambenoga fonda vidi se iz podatka da je 1991. u Zagrebu bilo ukupno 276.681, a 2001. godine 312.902 stana. U pogledu prosječne veličine stana projekcija GUP-a iz 1986. pokazala

\footnotetext{
97 Generalni urbanistički plan: osnove generalnog urbanističkog plana Zagreba, 230.

98 MARETIĆ, „Izgradnja stambenih naselja u Zagrebu”, 52; TIMET, Stambena izgradnja Zagreba do 1954. godine, 202.

99 Statistički godišnjak Zagreba 1991., 62.

100 Generalni urbanistički plan grada Zagreba: elaborat, 16; Generalni urbanistički plan: osnove generalnog urbanističkog plana Zagreba, 5.
} 
se točnom, naime 1991. prosječna veličina stana iznosila je $62,09 \mathrm{~m}^{2}$, a 2001 . bila je $64,93 \mathrm{~m}^{2} .101$

Programom iz 1965. predviđeno je povećanje gustoće naseljenosti s tadašnjih 172 na 185 stanovnika/ha, a GUP iz 1971. predviđa smanjenje na 162 stanovnika/ha. Iz popisa stanovništva 1981. i 1991. saznajemo da je 1981. gustoća naseljenosti iznosila 29,76 stanovnika/ha, a 1991. godine 31,81 stanovnika/ ha. ${ }^{102}$ Tako veliku smanjenju gustoće naseljenosti vjerojatno je razlog pripojenje dotadašnjih samostalnih naselja (Čučerje, Granešina, Miroševec, Slanovec, Jalševec i dr.) u cjelinu grada Zagreba.

Programom iz 1965. planirano je da bi za trideset godina od predviđenih 350.000 stanova najviše bilo trosobnih (26\%) te garsonijera i posebnih soba (26\%), potom dvosobnih (18,5\%), jednosobnih (12,5\%), četverosobnih $(11,9 \%)$ i s pet i više soba (5,1\%). Dok je u GUP-u iz 1971. predviđen udio garsonijera i jednosobnih stanova od 25,8 \%, program iz 1965. planirao je njihov udio od 38,5\%. Plan iz 1971. iznosi da bi udio dvosobnih stanova trebao porasti na $30,3 \%$, a udio trosobnih, četverosobnih i višesobnih bio bi 44,2 \%, dok je u programu iz 1965. planirano $43 \%$. Planom iz 1971. više nije planirana gradnja posebnih soba, kao ni u GUP-u iz 1986., koji predviđa povećanje stambene površine izgradnjom većih stanova. ${ }^{103}$

Tablica 2. Novoizgrađeni stanovi u Zagrebu 1956. do 1990. (izvor: Statistički godišsnjak Zagreba 1991., 62).

\begin{tabular}{|c|c|c|c|c|c|c|c|}
\hline \multirow[b]{2}{*}{ Period } & \multirow{2}{*}{$\begin{array}{c}\text { Novih } \\
\text { stanova }\end{array}$} & \multirow{2}{*}{$\begin{array}{l}\text { Ukupna povr- } \\
\text { šina stanova } \\
\qquad\left(\mathbf{m}^{2}\right)\end{array}$} & \multicolumn{5}{|c|}{ Vrsta stana } \\
\hline & & & $\begin{array}{c}\text { posebna } \\
\text { soba }\end{array}$ & 1-sobni & 2-sobni & 3-sobni & $\begin{array}{c}\text { 4- i više- } \\
\text { sobni }\end{array}$ \\
\hline 1956.-1960. & 11.484 & 581.733 & 759 & 3565 & 5629 & 1451 & 80 \\
\hline 1960.-1965. & 28.790 & 1.414 .394 & 1399 & 7760 & 14.346 & 4627 & 658 \\
\hline 1965.-1970. & 31.985 & 1.734 .934 & 193 & 8676 & 17.064 & 5365 & 687 \\
\hline 1970.-1975. & 34.963 & 1.884 .626 & 0 & 11.802 & 15.059 & 7090 & 1012 \\
\hline 1975.-1990. & 103.039 & 6.919 .966 & 0 & 24.169 & 35.080 & 29.462 & 14.328 \\
\hline $\begin{array}{c}\text { Ukupno } \\
1956 .-1990 .\end{array}$ & 210.261 & 12.535 .653 & 2351 & 55.972 & 87.178 & 47.995 & 16.765 \\
\hline $\begin{array}{c}\text { Udio } \\
\text { izgrađenih } \\
\text { stanova }\end{array}$ & $\mathbf{x}$ & $\mathbf{x}$ & $1,11 \%$ & $26,62 \%$ & $41,46 \%$ & $22,82 \%$ & $7,97 \%$ \\
\hline
\end{tabular}

101 BEŽOVAN, „Procjena standarda stanovanja u Zagrebu kao razvojnog resursa”, 28.

102 DAKIĆ, BEDENKO, MATTIONI, Zagreb 2000+ Nova urbana strategija, 39.

103 Urbanistički program grada Zagreba: smjernice za razvoj, 46; Generalni urbanistički plan grada Zagreba: elaborat, 16-17. 


\section{Zaključak}

U 45 godina socijalističkoga razdoblja u Zagrebu je izgrađeno ukupno oko 220.000 stanova. Do šezdesetih godina izgradnja je bila skromnija, najproduktivnije razdoblje je ono od 1961. do 1981., a u osamdesetima izgradnja ponovno stagnira. Predviđanja urbanističkih planova i programa o povećanju stambene površine po stanovniku i povećanju veličine stanova ostvarila su se, ali ne u onoj mjeri u kojoj je planirano. U gradu su najviše zastupljeni dvosobni i jednosobni stanovi, a potom trosobni, iako je planirano da se povećava broj upravo trosobnih stanova. Došlo je do odstupanja od projekcije o priljevu stanovništva i planiranoj izgradnji, što je rezultiralo povećanjem standarda života stanovnika Zagreba. U svrhu boljega standarda građana bile su predviđene velike zelene površine, GUP-om iz 1971. čak $60 \%$ površine grada, međutim zelene su površine ustupile prostor parkiralištima, a poslije trgovačkim centrima i sakralnim objektima.

Položaj stambenih zona, odnosno prostor stambene izgradnje bio je predviđen za središnji dio grada i Novi Zagreb, međutim kako se grad dijelom razvijao planski, a dijelom stihijski, obuhvaćene su velike površine i na istoku i na zapadu, a povećanju gradske površine znatno je pridonijela i izgradnja obiteljskih prizemnica na rubnim dijelovima grada, zbog čega je i gustoća stanovništva ostala relativno niska. Izgradnja obiteljskih kuća velikim dijelom ulazi u problematiku bespravne ili tzv. divlje gradnje, odnosno „divljih naselja”. Federalne i republičke vlasti prešutno su dozvoljavale bespravnu gradnju, time dijelom rješavajući stambenu problematiku, ali narušavajući urbanu sliku gradova. Problemom „divljih naselja” bavili su se urbanistički planovi i program, u kojima je predviđena u većoj ili manjoj mjeri njihova asanacija i/ili rušenje uz zbrinjavanje stanovnika, no ti planovi u najvećoj mjeri nisu ostvareni upravo zbog problema zbrinjavanja stanovnika.

Svi urbanistički planovi, program i prijedlog odraz su i duha vremena u kojem su nastali. Tako se u planu iz 1986. kazuje da je onaj iz 1971. dio „druge ekonomske i društvene realnosti” te da je riječ o gotovo utopijskom planu, dok je plan iz 1986. objektivniji i temelji se na „mjeri i postupnosti”. Prijedlog iz 1949./1953. vjerojatno bi se također mogao okarakterizirati kao utopijski, što je i razumljivo ako se uzme u obzir da je nastao tijekom poslijeratne izgradnje i obnove. Dokaz tomu planirani je tunel ispod Sljemena koji do danas nije realiziran. Programom iz 1965. predviđa se znatno povećanje standarda građana, ambiciozan je i u pogledu porasta stanovništva i izgradnje objekata, a zanimljiv zbog mogućnosti izgradnje nuklearne centrale, te je također pokazatelj vremena koje odlikuje veliki rast bruto domaćega proizvoda i kvalitete života. Možda je paradoksalno da je GUP iz 1986. - nastao kada su pokazatelji život- 
noga standarda bili najdinamičniji (priključci na vodovod, kanalizaciju, plin, električnu mrežu i telefonski priključci) - najskromniji u planovima izgradnje i sveukupnoga razvoja grada, a s druge strane možda je upravo odraz osamdesetih godina, kada Hrvatsku i Jugoslaviju zahvaća ekonomska, politička i društvena kriza.

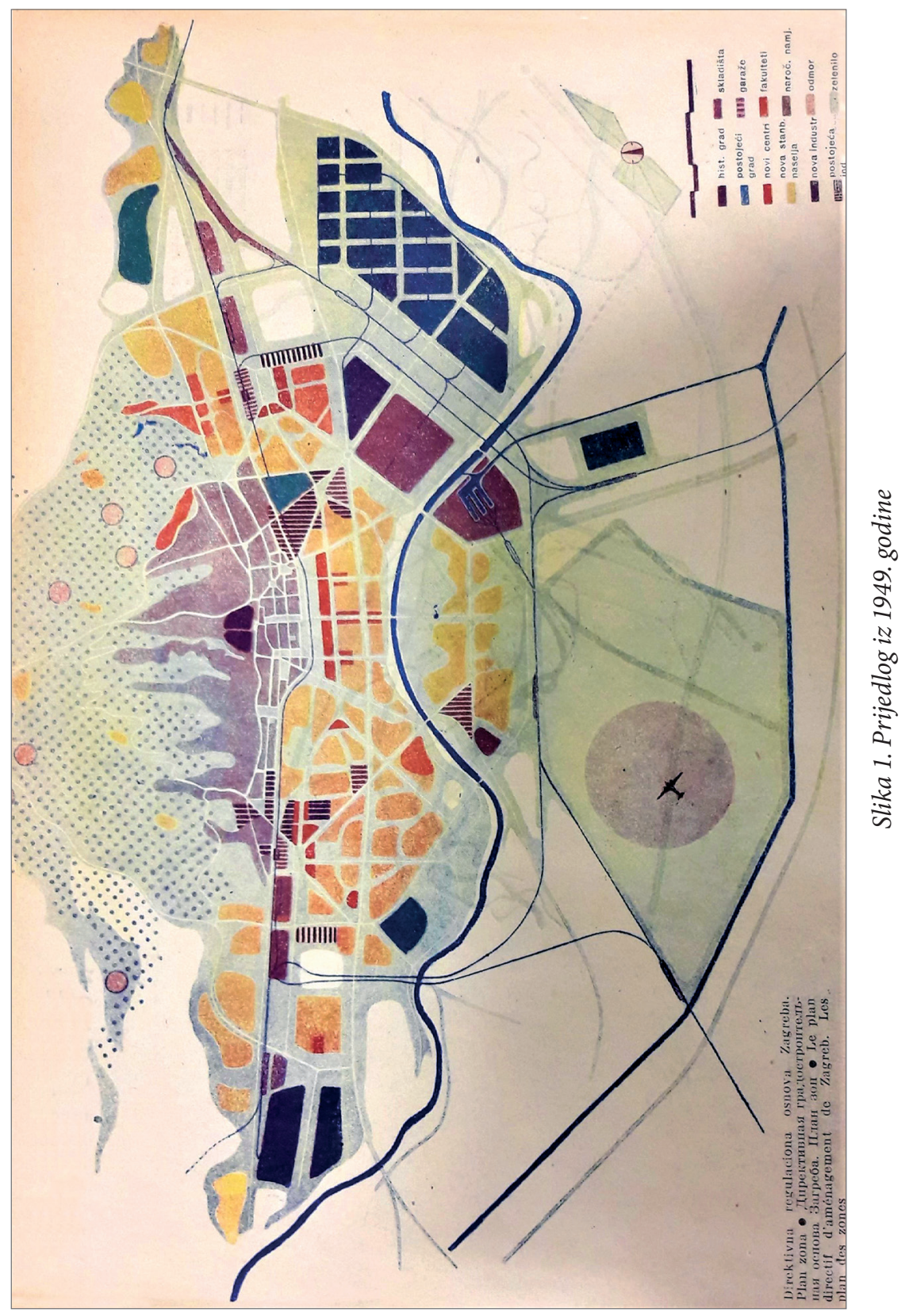




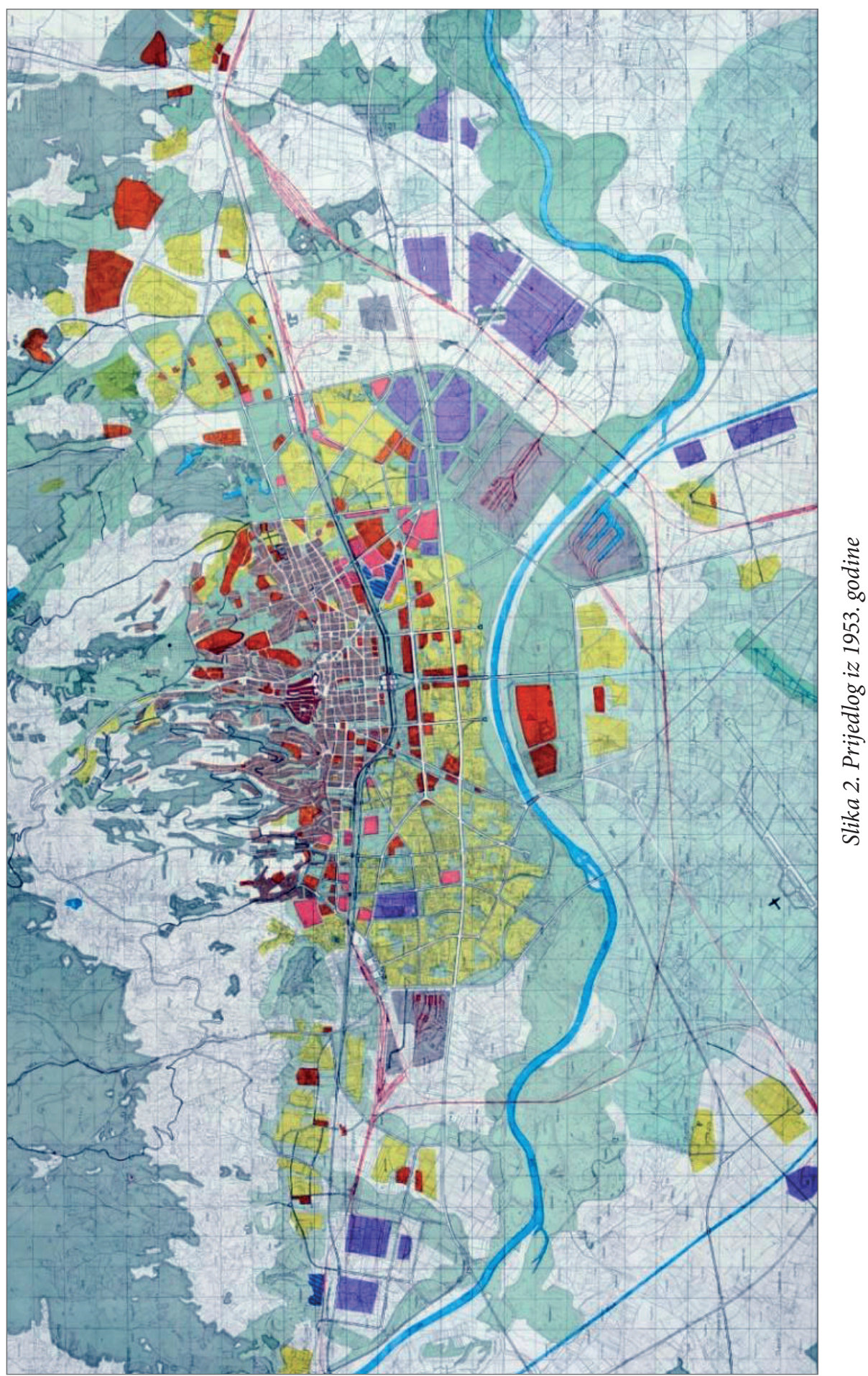




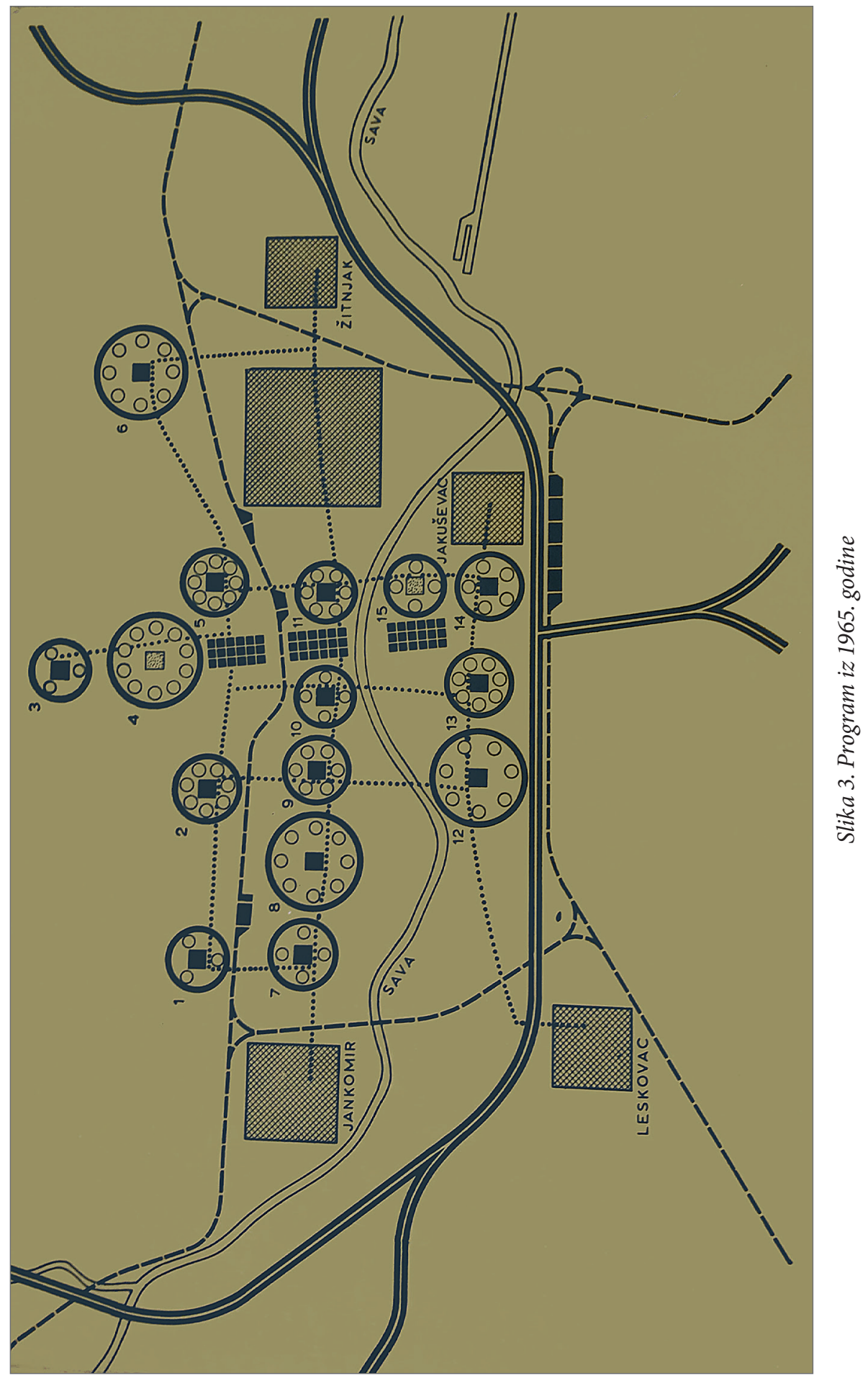




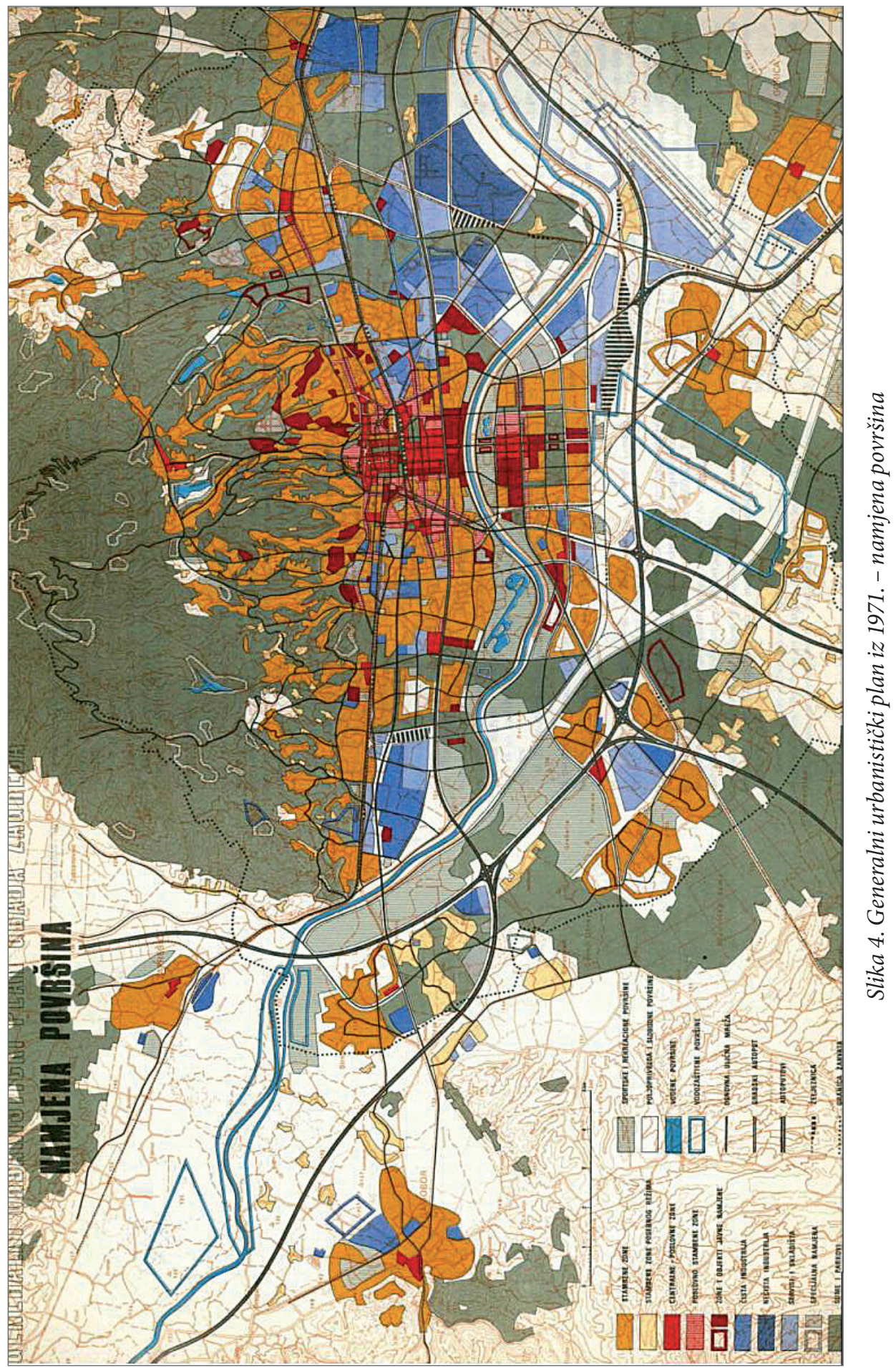




\section{Arhivski izvori}

HR-DAZG-NOGZ-37.1 SPT: Hrvatska, Državni arhiv u Zagrebu, Zagreb, fond 37, Narodni odbor grada Zagreba, podfond 1, Sjednice predstavničkih tijela.

HR-DAZG-NOGZ-37.3 SIT: Hrvatska, Državni arhiv u Zagrebu, Zagreb, fond 37, Narodni odbor grada Zagreba, podfond 3, Sjednice izvršnih tijela.

\section{Objavljeni izvori}

ANTOLIĆ, Vlado. „Regulacioni plan i direktivna regulaciona osnova Zagreba”. Arhitektura 3 (1949), br. 18-22: 5-30.

Generalni urbanistički plan grada Zagreba: elaborat. Zagreb: Urbanistički zavod grada Zagreba, 1970.

Generalni urbanistički plan grada Zagreba: prva projekcija. Zagreb: Urbanistički zavod grada Zagreba, 1970.

Generalni urbanistički plan grada Zagreba: sažetak. Zagreb: Urbanistički zavod grada Zagreba, 1985.

Generalni urbanistički plan: osnove generalnog urbanističkog plana Zagreba. Zagreb: Urbanistički zavod grada Zagreba, 1983.

Urbanistički program grada Zagreba: smjernice za razvoj. Zagreb: Urbanistički zavod grada Zagreba, 1965.

Zagreb: direktivna regulatorna osnova Zavoda za urbanizam NOGZ 1953. Zagreb: Zavod za urbanizam NOGZ, 1953 [zemljopisna karta].

\section{Mrežne poveznice}

„Antolić, Vlado”. U: Hrvatska enciklopedija (on-line), Leksikografski zavod „Miroslav Krleža”. Pristup ostvaren 26. 2. 2020. https://www.enciklopedija.hr/ natuknica.aspx?ID=3142.

„Bakal, Aleksandar”. U: Hrvatski biografski leksikon (on-line), Leksikografski zavod „Miroslav Krleža”. Pristup ostvaren 26. 2. 2020. https://hbl.lzmk.hr/ clanak.aspx?id=1084.

„Holjevac, Većeslav”. U: Hrvatski biografski leksikon (on-line), Leksikografski zavod „Miroslav Krleža”. Pristup ostvaren 10. 5. 2020. http://hbl.lzmk.hr/ clanak.aspx?id=67. 
„Kolacio, Zdenko”. U: Hrvatski biografski leksikon (on-line), Leksikografski zavod „Miroslav Krleža”. Pristup ostvaren 26. 2. 2020. http://hbl.lzmk.hr/ clanak.aspx?id=226.

„Uhlik, Josip”. U: Hrvatska enciklopedija (on-line), Leksikografski zavod „Miroslav Krleža”. Pristup ostvaren 26. 2. 2020. https://www.enciklopedija. hr/natuknica.aspx?id=63034.

\section{Literatura}

BAKAL, Aleksandar. „30 godina Urbanističkog zavoda grada Zagreba”. U: 30 godina Urbanističkog zavoda grada Zagreba: 1957-1987, ur. Radovan Delalle. Zagreb: Urbanistički zavod grada Zagreba, 1987, 3-4.

BARA, Mario. „Modernizacija urbanoga života u Hrvatskoj kroz prizmu stambenih i komunalnih politika u razdoblju socijalizma”. Časopis za suvremenu povijest 52 (2020), br. 1: 9-33.

BEŽOVAN, Gojko. „Procjena standarda stanovanja u Zagrebu kao razvojnog resursa”. Revija za socijalnu politiku 12 (2005), br. 1: 23-44.

DAKIĆ, Slavko. „Generalni urbanistički plan grada Zagreba”. U: 30 godina Urbanističkog zavoda grada Zagreba: 1957-1987, ur. Radovan Delalle. Zagreb: Urbanistički zavod grada Zagreba, 1987, 5-6.

DAKIĆ, Slavko; BEDENKO, Višnja; MATTIONI, Vladimir, ur. Zagreb 2000+ Nova urbana strategija: Generalni urbanistički plan Zagreba. Zagreb: Gradski zavod za planiranje razvoja grada i zaštitu okoliša, 2000.

DELALLE, Radovan, ur. 25 godina Urbanističkog zavoda grada Zagreba: 1957-1982. Zagreb: Urbanistički zavod grada Zagreb, 1982.

DOMLJAN, Žarko. „Poslijeratna arhitektura u Hrvatskoj”. U: O hrvatskoj arhitekturi, ur. Neven Šegvić. Zagreb: Arhitektonski fakultet Sveučilišta u Zagrebu, 1992, 91-99.

FRANKOVIĆ, Eugen. „Urbanističko planiranje Zagreba od 1945. do 1985." Radovi Instituta za povijest umjetnosti (1985), br. 9: 85-87.

MARETIĆ, Mirko. „Izgradnja stambenih naselja u Zagrebu”. Arhitektura 24 (1970), br. 107-108: 48-59.

PETRINJAK-ŠIMEK, Vera. „Programi zaštite prostora”. U: 30 godina Urbanističkog zavoda grada Zagreba: 1957-1987, ur. Radovan Delalle. Zagreb: Urbanistički zavod grada Zagreba, 1987, 10.

Službeni glasnik Narodnog odbora grada Zagreba (Zagreb), 1954.

Statistički godišnjak Zagreba 1991. Zagreb: Zavod za statistiku i evidenciju Narodnog odbora grada Zagreba, 1991. 
TIMET, Tomislav. Stambena izgradnja Zagreba do 1954. godine. Zagreb: Jugoslavenska akademija znanosti i umjetnosti, 1961.

\section{SUMMARY}

\section{Zagreb Housing Construction in Draft Plans and Master Plans from 1945 to 1990}

The issue of securing housing for each member of a society as well as the quality of its construction are among the key challenges faced by every society as a whole, but also by every political system. Housing was one of the main social and political issues during the socialist period in Croatia. In urban areas, the goal was to create an all-encompassing housing policy that would be implemented via master plans and urban planning programmes. This problem was worked on continuously by the Urban Planning Institute of Zagreb City and its legal predecessors, primarily through urban planning proposals and plans published in 1949, 1953, 1965, 1971, and 1986. The research presented here is based on the master plans of Zagreb (regulatory bases), one urban development programme, and two urban development proposals: Vlado Antolić, 'Regulacioni plan i direktivna regulaciona osnova Zagreba' [Regulatory Plan and Directive Regulatory Basis of Zagreb], Arhitektura (1949); Zagreb: direktivna regulatorna osnova Zavoda za urbanizam NOGZ 1953. [Zagreb: Directive Regulatory Basis of the Zagreb City People's Committee Urban Planning Institute, 1953] (1953); Urbanistički program grada Zagreba: smjernice za razvoj [Urban Planning Programme of the City of Zagreb: Development Guidelines] (1965); Generalni urbanistički plan grada Zagreba: elaborat [Zagreb City Master Plan: Report] (1970); Generalni urbanistički plan grada Zagreba: sažetak [Zagreb City Master Plan: Summary] (1985). This paper attempts to determine which systemic solutions were anticipated, what were the projections of the city's development and population trends, and how the urban planning proposals and plans were implemented.

Key words: Zagreb; Croatia; Yugoslavia; socialism; housing construction; housing problem; master plan; regulatory bases; urban planning 